\title{
The Past and its Possibilities in Nahḍa Scholarship
}

\author{
Feras Krimsti \\ Gotha Research Library, University of Erfurt, Gotha, Germany \\ feras.krimsti@uni-erfurt.de \\ John-Paul Ghobrial \\ Faculty of History and Balliol College, University of Oxford, Oxford, UK \\ john-paul.ghobrial@history.ox.ac.uk
}

\begin{abstract}
This introduction to the special issue "The Past and its Possibilities in Nahda Scholarship" reflects on the role of the past in nineteenth- and early twentieth-century nahda discourse. It argues that historical reflection played a pivotal role in a number of scholarly disciplines besides the discipline of history, notably philosophy and logic, grammar and lexicography, linguistics, philology, and adab. Nahdawis reflected on continuities with the past, the genealogies of their present, and the role of history in determining their future. The introduction of print gave new impulses to the engagement with the historical heritage. We argue for a history of the nahda as a de-centred history of possibilities that recovers a wider circle of scholars and intellectuals and their multiple and overlapping local and global audiences. Such a history can also shed light on the many ways in which historical reflection, record-keeping practices, and confessional, sectarian, or communalist agendas are entwined.
\end{abstract}

\section{Keywords}

past - history - nahda - nineteenth- and early twentieth-century scholarship - Eastern Christianity

When the two hundredth anniversary of the death of the Maronite Bishop Jirmānūs Farhạat (1670-1732) was celebrated in Aleppo in May 1934, during the French Mandate, several hundreds of the city's inhabitants along with religious and political elites gathered for the unveiling of a statue of Farhāt in the 
festively decorated central square of the quarter al-Judayda, a hub of Christian religious and economic activity. The statue, depicting Farḥāt majestically sat on his throne, had been elevated on a pedestal in front of the Maronite and Melkite, or Greek Catholic, churches. In preparation for the celebrations, it had been draped by a French and a Syrian flag. Before a youthful crowd, politicians and church dignitaries unveiled the statue and gave moving speeches in celebration of the day. They lauded Farhāt as a "pioneer" of the nahda, alongside other luminaries from eighteenth-century Aleppo, among them notably 'Abdallāh Zākhir (1684-1748), a Melkite intellectual and the founder of an early printing press, and Nīqūlā Sāigh (1692-1756), the superior general of the Melkite Shuwayrite order and a renowned poet. ${ }^{1}$

Maronite Christians were especially prominent among the speakers at the occasion. Aghnātịūs Sa'd, the Maronite priest who had collected the money for the statue and organized the festivities, spoke first, and other Maronite monks and dignitaries followed suit, including Aghnātiyūs Mubārak, the Maronite Bishop of Beirut. Besides Maronites, Christians from other communities joined the festivities. Europeans, especially those who served as diplomats under the French Mandate, were also present: the High Commissioner Count Damien de Martel (1878-1940), for example, sent his assistant delegate Monsieur Lavastre. Muslim statesmen and notables were no less involved in the festivities: Muhammad al-Ābid (1867-1939), the President of the Syrian Republic between 1932 and 1936, was present, and so was the Syrian Minister of Defence, Abd al-Rahmān al-Kayyālī (1887-69). The latter was a son of one of Aleppo's prominent $a$ 'yān families.

We only know of the circumstances of the celebration and the speeches and poems recited by the aforementioned illustrious figures on that day in May 1934 because they were later published, alongside a number of photographs of the event, in order to be circulated among those who could not join the celebrations in person. Aghnāțiyūs Sacd was in all likelihood behind the publication of the material in written form. The fact that the accounts appeared

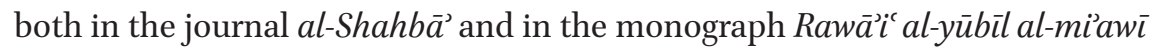
al-thān $\bar{\imath}$ in the very same year shows that the speeches were widely diffused and popular. Clearly, whoever was responsible intended that the event should

1 On the celebrations, see the journal al-Shahbä' 9, no. 1, 2, 3 (1934). They were published a

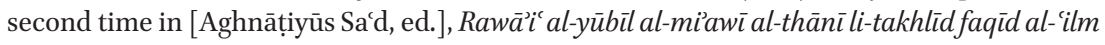
wa-l-fậila al-nābigha al-Muṭrān Jirmānūs Farhạat, 2 parts in 1 volume (Aleppo: al-Mațba'a al-Mārūniyya, 1934). Since the journal and the book's second part are identical, we will refer in what follows exclusively to the Rawā'i al-yübïl. 


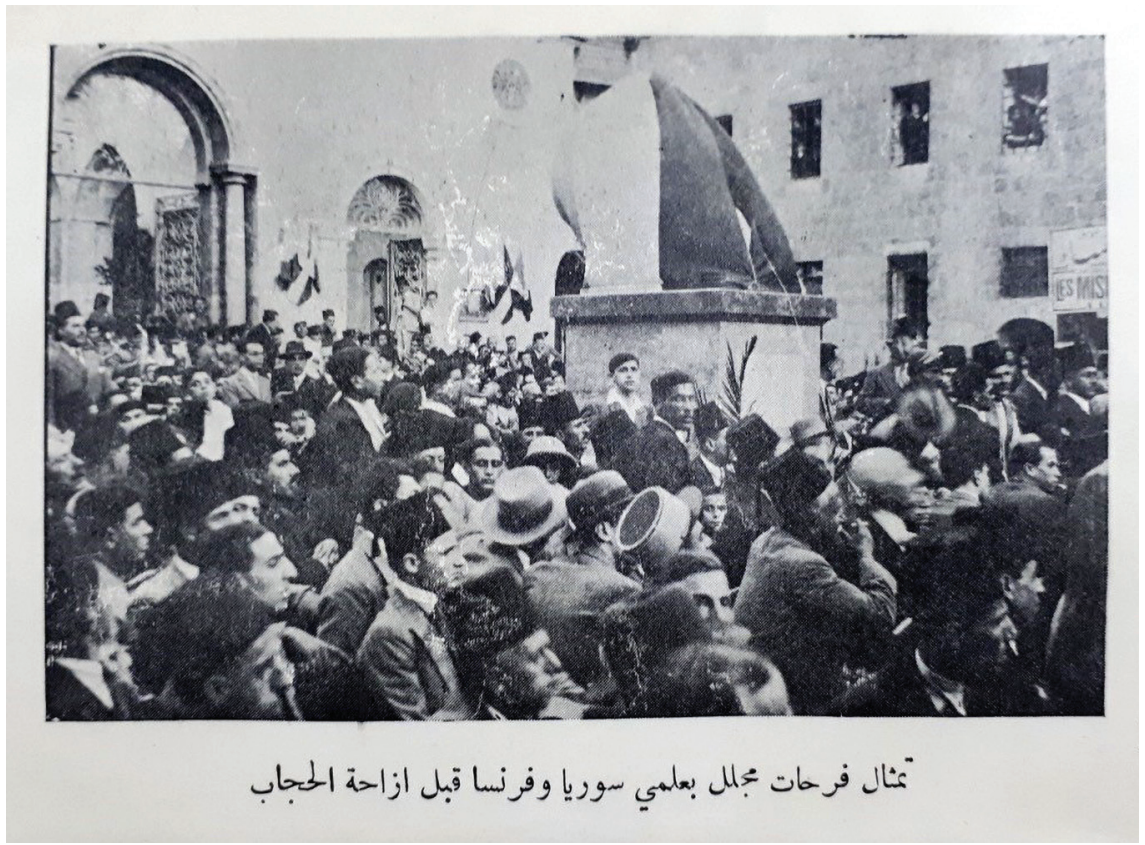

FIG. 1 Celebration of the two hundredth anniversary of the death of Jirmānūs Farhāt, on 20 May 1934 in Aleppo (before the unveiling of the statute). Photograph published in al-Shahbā' 9, no. 1, 2, 3 (1934), after p. 24. Digital image courtesy of La Bibliothèque Spirtuelle d'Alep.

leave an impression on a far greater public than the crowd of a few hundred people pictured above and below (see figs. 1 and 2 ).

In the speeches that were given that day, the past played a very important role. Aghnāțiyūs Sad encouraged the audience to erect further statues of Aleppo's luminaries. He proposed statues for the poets al-Mutanabbī (915-65), al-Ma'arrī (973-1057), and Nīqūlā Sāigh, ${ }^{2}$ thereby reconnecting Farhāât and Aleppo's Christian litterateurs of the seventeenth and eighteenth centuries to the classical age. In a similar vein, he addressed his listeners as "grandsons" of the patron of poets Sayf al-Dawla (916-67), the aforementioned Abbasid poets al-Mutanabbī and al-Ma'arrī, as well as further classical poets and litterateurs such as al-Buhturīi (821-97) and Abū Firās al-Ḥamdānī (932-68), alongside celebrated Christian figures of the seventeenth and eighteenth centuries such as Sā'igh and Zākhir. ${ }^{3}$ In this way, Sad subtly blended the admired classical period

2 [Sa'd, ed.], Rawā̇ic al-yūbül, 2:4.

3 [Sacd, ed.], Rawä̈i al-yūbül, 2:33. 


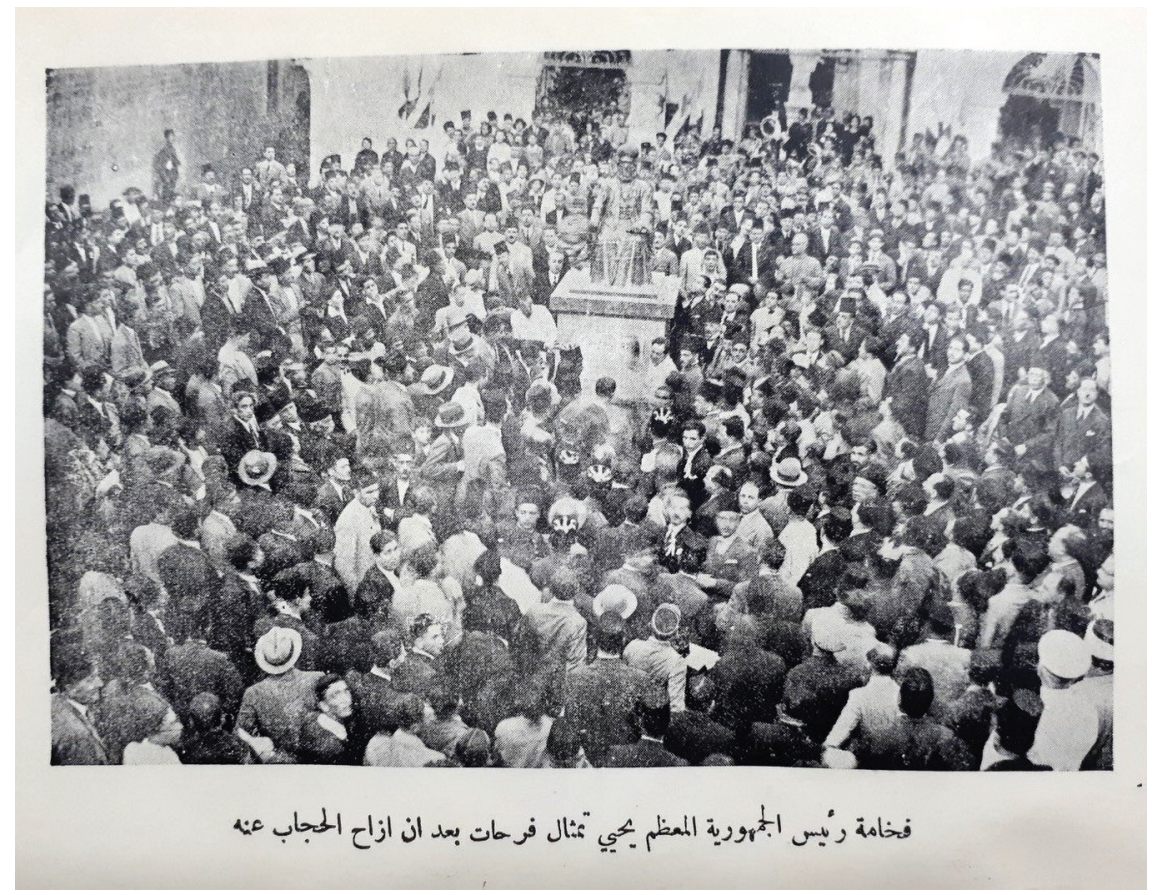

FIG. 2 The statue of Jirmānūs Farhāāt unveiled in May 1934. Photograph published in al-Shahbä' 9, no. 1, 2, 3 (1934), after p. 47. Digital image courtesy of La Bibliothèque Spirtuelle d'Alep.

with what he perceived to be a time of Christian intellectual revival anticipating the hopeful present of the nahda.

In the historical reflections sewn into these speeches, the Arabic language played a pivotal role. A recurring idea about the past that a number of speakers articulated was the idea that Farhạat had managed to reacquaint Christians with the Arabic language from which they had become alienated. With this revival and reappropriation of Arabic, he had prepared the ground for a "linguistic unification" (tawhìd al-lugha), as one of the speakers, a priest named Anțūniyūs 'Ārij, put it. ${ }^{4}$ Farḥāt's work on Arabic thus initiated a rapprochement between Christians and Muslims, an "Islamic-Christian unity" (al-ittihäd al-is(āmi al-masīhī) that made itself present and felt in the speakers' own times. ${ }^{5}$ However, the presence of representatives from different religious communities and frequent invocations of unity, harmony, and cohesion should not

4 [Sacd, ed.], Rawā’i al-yūbïl, 2:57.

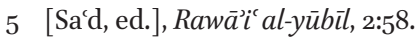


obscure the fact that intercommunal tensions were in the air. These tensions were to erupt only two years later in the so called "Sunday Market Incident" in Aleppo, an outburst of violence that involved paramilitary groups with fascist ideas and resulted in five casualties and hundreds of wounded. ${ }^{6}$ Yet during the celebration in 1934, speakers like Anțūniyūs 'Ārij developed a version of the past that allowed them to express presentist nationalist agendas full of hope for unity.

Farhāt's eulogists were unanimously positive about the historical Farhāat, but they found significantly less laudatory words for the historical period in which he actually lived. Although they mostly spoke about Ottoman rule in allusions, they invoked an era of intellectual stagnation. One of the speakers at the celebration, a Lebanese monk named 'Abdallāh Rīgha, who belonged to a monastic order founded by Farḥāt and about whom virtually nothing is known today, was more explicit. ${ }^{7} \mathrm{He}$ used a gloomy allegory:

Let us revisit these dark times-may God not allow them to returnlet us revisit a day when the shackles of servitude were tightened in this good Arab place. Space for talents shrank, resolve weakened, and the spring of poetry ran dry. The elements that defended the language of the $d \bar{a} d$ [i.e., the Arabic language] became weak. Thoughts inclined towards the prevention of calamities, which had different sources and appeared in different ways. Let us revisit this moment to catch a glimpse of that barren desert. Through the reflections of the mirage, we see a tall branch. Look at it from up close: the branch fights against its environment and vanquishes it. It grows and bears two ripe fruits: religion and science. That branch is Farhāat, and religion and science are his venerable legacy pointing to him. ${ }^{8}$

6 Keith David Watenpaugh, Being Modern in the Middle East: Revolution, Nationalism, Colonialism, and the Arab Middle Class (Princeton [NJ]: Princeton University Press, 2006), $271-78$.

7 For 'Abdallāh Rīghā's speech, see [Sa‘d, ed.], Rawā̄i al-yūbül, 2:44-48. (It is concluded with a poem.)

8 [Sacd, ed.], Rawā'i $i^{\prime}$ al-yūbül, 2:45:

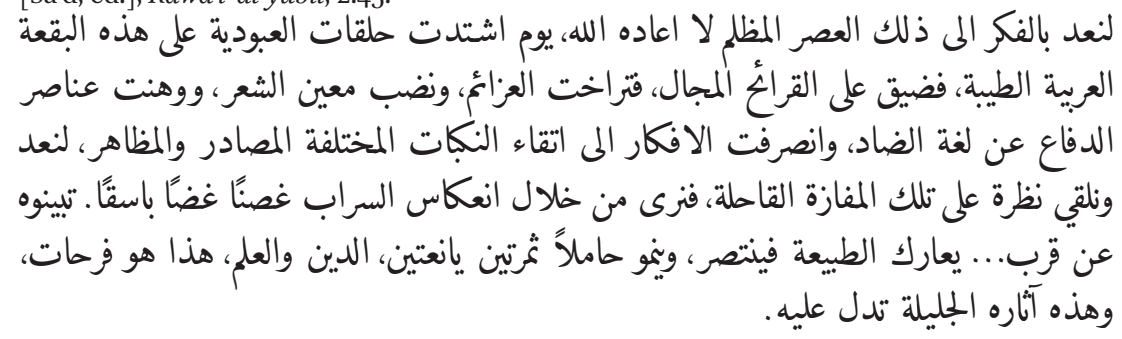


The past was very present in the speeches that were given at the celebration in honour of Farhăt. We have so far encountered the golden era of the Abbasids, the barren period of Ottoman decline, and the hopeful times of eighteenth-century Christian revival. These are only three among a number of pasts that nahdawis turned to, for a variety of reasons and with a number of goals in mind. We might add to these biblical times, the jāhiliyya (often translated as "time of ignorance") before the rise of Islam in the seventh century, the Crusades, and the Napoleonic expedition, to name just a few more significant pasts that we regularly encounter in nineteenth- and early twentieth-century works. In this way, Sa'd, 'Ārij, and Rīgha's speeches on that day in May 1934 capture the important role played by the past in the self-conception, imagination, and aspirations of nahdawis. Like many of their contemporaries, they sought to control the past in order to understand the present and chart a way into the future.

This special issue of Philological Encounters is dedicated to the question of what role exactly the past played in nineteenth- and early twentieth-century nahda discourse. ${ }^{9}$ While modern scholarship on the nahda has tended towards a focus on progress, change, and rupture, comparatively little attention has been given to how nahdawis used the past as a foil to give their own thought and self-understanding a distinct profile, particularly those nahdawis who contributed to and engaged in the development of new scholarly discourses and study tools. Recent scholarship on history and historiography in the nineteenth and early twentieth centuries has alerted us to the importance of the past for individuals and scholars who struggled to come to grips with the experience of modernity. In fact, in academic debates in late nineteenth- and early twentiethcentury Egypt, history has been shown to have functioned as the "foremost medium through which it [i.e., modernity] was articulated."10 Further works also have embraced a greater interest in the engagement of nahdawis and nineteenth-/early twentieth-century intellectuals with time and temporalities more generally: they have discussed historical myth, ${ }^{11}$ the past and memory, ${ }^{12}$

For a detailed discussion of the history and historiography of the nahda, see Jens Hanssen and Max Weiss, "Introduction: Language, Mind, Freedom and Time: The Modern Arab Intellectual Tradition in Four Words," in Arabic Thought Beyond the Liberal Age: Towards an Intellectual History of the Nahda, eds. Jens Hanssen and Max Weiss (Cambridge: Cambridge University Press, 2016), 1-37.

10 Yoav Di-Capua, Gatekeepers of the Arab Past: Historians and History-Writing in TwentiethCentury Egypt (Berkeley/London: University of California Press, 2009), 18.

11 Kamal Salibi, A House of Many Mansions: The History of Lebanon Reconsidered (London: I.B. Tauris, 1988), especially $108-29$ and $130-5$ o.

12 Karl K. Barbir, "Memory, Heritage, and History: The Ottoman Legacy in the Arab World," in Imperial Legacy: The Ottoman Imprint on the Balkans and the Middle East, ed. L. Carl Brown (New York: Columbia University Press, 1996), 100-114. 
figurations of the future and utopias, ${ }^{13}$ periodization, ${ }^{14}$ the tensions between the revival of the past and a revolutionary future, ${ }^{15}$ the invention of history and dialectical historiography, ${ }^{16}$ the use of established genres like biography in the communication of history through modern print media, ${ }^{17}$ the narrative heritage of nationalism that linked past and present, ${ }^{18}$ different representations of one and the same past by historians, ${ }^{19}$ and the relation between evolutionary theory and debates about decline and progress, ${ }^{20}$ to name but a few exemplary topics. Yet despite many of these promising insights, the study of the past and history during the nahda is still only in its initial stages. This special issue cannot replace detailed studies that explore specific figurations of the past at work in scholarly and academic discourse of the nineteenth and early twentieth centuries, but it is intended to stimulate interest in the topic and to point to potential avenues of future research.

\section{Uses of the Past in the Nahda}

That such comparatively insignificant and unknown figures as Sacd, 'Ārij, and Righa managed to circulate their visions of the past to wider audiences in this way betrays the extent to which a wide range of unstudied individuals

13 Peter Hill, Utopia and Civilisation in the Arab Nahda (Cambridge: Cambridge University Press, 2020).

14 Hanssen and Weiss, "Introduction," 29-37; Dana Sajdi, "Decline, its Discontents and Ottoman Cultural History: By Way of Introduction," in Ottoman Tulips, Ottoman Coffee: Leisure and Lifestyle in the Eighteenth Century, ed. Dana Sajdi (London: I.B. Tauris, 2007) $1-40$.

15 Orit Bashkin, "Looking Forward to the Past: Nahda, Revolution, and the Early Ba'th in Iraq," in Other Renaissances: A New Approach to World Literature, eds. Brenda Deen Schildgen, Gang Zhou, and Sander L. Gilman (Basingstoke: Palgrave Macmillan, 20o6), 59-86.

16 Anthony Edwards, "Fact or Fiction? In Search of the 'Learned Council' of Ğirmānūs Farhāat," Journal of Arabic and Islamic Studies 18 (2018): 1-21.

17 Marilyn Booth, Classes of Ladies of Cloistered Spaces: Writing Feminist History through Biography in Fin-de-siecle Egypt (Edinburgh: Edinburgh University Press, 2015), especially 31-94; Barbara Winckler, "Embarking upon a New Era through an Old Genre: Biographical Essays in Journals of the Nahḍah Period-Ǧurğī Zaydān and al-Hilāl's Early Years as Example," Oriente Moderno 99 (2019): 68-93.

18 Peter Wien, Arab Nationalism: The Politics of History and Culture in the Modern Middle East (Abingdon: Routledge, 2017).

19 Michael J. Reimer, "Egyptian Views of Ottoman Rule: Five Historians and Their Works, 1820-1920," Comparative Studies of South Asia, Africa and the Middle East 31, no. 1 (2011): 149-163.

20 Marwa Elshakry, Reading Darwin in Arabic, 1860-1950 (Chicago: The University of Chicago Press, 2014). 
contributed in critical ways to uses of the past as a crucial element in nahda discourse. Intellectuals, clergymen, religious thinkers, missionaries, schoolteachers, women activists and novelists, litterateurs, and scholars of the nineteenth and early twentieth centuries were all simultaneously involved in a project to make sense of a variety of pasts, even as they looked towards the future, towards religious reform and towards cultural and political change.

Not only did nahdawis turn their attention to several different periods in the past, but their engagement with the past expressed itself through a wide variety of practices during the nineteenth and early twentieth centuries. As the contributions in this special issue make clear, nahdawis did not only engage with the written sources, but they also looked for traces of the past in the material, archaeological, numismatic, and even architectural record around them. Yet this work of sifting through the records of the past existed for many contemporaries alongside a second energetic and activist impulse. Practices and activities like the creation of archives, the erection of statues, and above all the documentation of the past through the written word reflected this activism. Nahdawiss edited and published old manuscripts, printed historical chronicles, and established historical societies, methods, and curricula.

When faced with the myriad textual and material records of the past, nineteenth- and early twentieth-century writers displayed an incredibly creative approach to different periods of the Middle Eastern past. Sometimes the past, or rather, a past, needed to be revived, or, alternatively, it needed to be rejected and erased. In other times, a past had potential for creative use in the present, even if it needed to be altered, edited, or completely rewritten. Between these two ends of the spectrum there lay an infinite variety of possibilities for the ways nahdawis engaged with past events and history. The Jesuit scholar Louis Cheikho (1859-1927), for example, revived the jāhiliyya, but populated it with Christian rather than pagan poets, as demonstrated in Nora K. Schmid's contribution to this issue. Bülus Qaralī (d. 1952), following an old polemical trope, suggested that Islam emerged because the Prophet Muhammad brought the "spark" of Christianity from Syria to the Bedouin Arabs, but only after he had altered the original Christian message in significant ways. ${ }^{21}$ Muhammad Saīd al-Qāsimī (d. 1900), an important figure of the Islamic reform movement, heavily edited the chronicle of Ibn Budayr, the so-called "Barber of Damascus," thereby affirming eighteenth-century local history, but removing

21 See Būlus Qar’alī, al-Nașrāniyya wa-l-Islām: Difā' mansūb ilā al-ab Jurjus Rāhib Dayr Mār Sam`ān al-Bahrī (Bayt Shabāb: Mațba'at al-'Alam, 1933), 9. 
all its affinities to oral epic through linguistic "improvements." 22 In his contribution to this issue, Anthony Edwards offers another possibility in the person of the Protestant Anglophile Antonius Ameuney (1821-1881), who projected his own childhood onto a land reminiscent of the Bible, but jettisoned the recent Syrian past and advocated for its replacement with a Protestant civil society for the benefit of future generations.

Since these forms of engagement with the past occurred in scholarly works, their authors occasionally resorted to momentous linguistic and philological interventions, which is a recurring theme of many contributions to this issue. These interventions met with fervent opposition and resistance from others who had their own contested views of the same pasts: Habīb Zayyāt (1874-1954), for example, criticized Qusțanțin al-Bāshā's 1930 edition of the Damascene Mikhā̄il Burayk's eighteenth-century chronicle because al-Bāshā had introduced linguistic alterations and bowdlerized the text, arguably taking side with the Catholics against the Orthodox. ${ }^{23}$ In this way, views of the past played a crucial role in contemporary polemics and debates taking place within specific communities, even as these debates played out in Arabic journals, publications, and works that often had a regional or even global audience.

Nahda discourse has obscured the importance of the engagement with history and 'what was,' not least because those immersed in it put emphasis on the concept of "progress" (taqaddum), and attendant concepts like "civilization" (tamaddun) and "success" (najäh). The discourse of progress shows signs of emerging as early as the first half of the nineteenth century. It is noticeable, albeit in still uncertain form, in the address to readers at the beginning of Khalil al-Khūrì's journal Hadīqat al-akhbār ("Garden of News"), which appeared for the first time on 1 January $1858 .{ }^{24}$ It found an even earlier expression in Rifā'a Rāfi al-Ṭahțāwì's account of his stay in France, in which he discussed the "progress" of the people of Paris in the sciences, arts, and crafts. ${ }^{25}$ Basing himself on al-Ṭahțāwī's discussion, the Moroccan scholar Muhammad al-Ṣaffār, who visited France in $1845^{-46}$, also lauded the Parisian craftsmen's "progress." ${ }^{26}$ Ideas

22 See Dana Sajdi, The Barber of Damascus: Nouveau Literacy in the Eighteenth-Century Ottoman Levant (Stanford: Stanford University Press, 2013), 174-204.

23 See Ḥabīb Zayyāt, Review of "Tārīkh al-Shām li-l-Khūrī Mīkhā̄il Burayk," al-Mashriq 35 (1937): 209-217.

24 For an analysis of Khalīl al-Khūrì's address to the readers, see Hill, Utopia, 87-93.

25 See Rifaca Rafi al-Tahtawi, An Imam in Paris: Account of a Stay in France by an Egyptian Cleric (1826-1831), trans. Daniel L. Newman (London: Saqi, 2004), 254-76.

26 See Muhammad al-Ṣaffār, Disorienting Encounters: Travels of a Moroccan Scholar in France in 1845-1846: The Voyage of Muhammad aș-Ṣaffār, ed. and trans. Susan Gilson Miller (Berkeley: University of California Press, 1992), 157. 
of an autogenetic individual and national progress are found in the works of many other nahdawis. ${ }^{27}$

Mindful of this problem, the contributors to this special issue reverse the gaze. The issue is based on a workshop in the framework of which participants were encouraged to think not about the present or the future as aspirations in nahda scholarship but specifically about the use of the past. The workshop, "The Early Modern Christian Cultural and Literary Heritage in the Eyes of Nahḍa Scholars", was convened on 26-27 June 2019 at the University of Oxford, as part of the ERC-funded project "Stories of Survival: Recovering the Connected Histories of Eastern Christianity in the Early Modern World" $\left(2015^{-2020}\right)$. The contributions addressed a wide range of questions related to the early modern cultural and literary heritage as perceived by nahda scholars and intellectuals, especially Christians. By looking back rather than forward, into the past rather than into the future, the contributions to the special issue question the strong teleology that infused the work of many a nahdawi , a teleology that continues to imprint itself upon scholarly discourse to this day. In doing so, the contributions shed light on how nahdawis themselves reflected on continuities with the past, the genealogies of their present, and the role of history in determining their future.

The articles in this special issue can be gathered into two main groups, which explore the role of the past in nahda scholarship from two different perspectives. The first group comprises the contributions by Peter Hill, Anthony Edwards, Nora K. Schmid, and Hilary Kilpatrick, and offer a set of case studies of specific nahda writers with particular attention given to the way they used the past in their scholarship. All four scholars and writers discussed by the authors were Christians whose intellectual formation was touched in some way by European institutions either in the Middle East or abroad. Moreover, they all spent significant periods of time either in Europe or in the United States. As will become clear in the issue, these experiences contributed in distinct ways to the approaches they developed to the Middle Eastern past. Where previous approaches have recognized for some time the contribution of Christian writers to the nahda, the articles in this special issue demonstrate in poignant ways the great extent to which these Christian writers were closely integrated into the wider network of Muslim and Christian scholars and nahdawis that we know from previous works while they also interacted in important ways with European orientalists in this period.

27 An example is Buțrus al-Bustānī. See Stephen Sheehi, "Unpacking Modern Arab Subjectivity: Reading al-Mu'allim Butrus al-Bustani's 'Nafir Suriya,"' The Arab Studies Journal 6, no. 1 (1998): 87-99, especially 88-89. 
The second group of articles comprises contributions by Salam Rassi, Torsten Wollina, and Rossella De Luca, which highlight the continuity of scholarly practices that connected nahdawis to the generation(s) of scholars and writers before them. Philological and textual practices were based on, and innovatively developed, earlier Ottoman and early modern ways of working with texts. Clearly, the technology of print had a transformative impact on these practices. However, rather than destroying the intellectual genealogies that reach into the past, the merging of manuscript with print culture gave strong impulses for a creative engagement with earlier literary and intellectual traditions. ${ }^{28}$ There was a clear link between the introduction and flourishing of print and the (re-)discovery of the past during the late nineteenth and early twentieth centuries. As Ahmed El Shamsy has shown recently, print technology led to the revival of forgotten works and in Islamic thought it led to the emergence of a new "classical canon." ${ }^{29}$ This is true in many ways for Christians as well. In fact, all religious communities participated in the canonization process. Christians were involved, for example, in commentarial and scribal/ printing practices revolving around works of grammar, logic, and rhetoric by medieval Muslim authors, as demonstrated by Salam Rassi in his contribution to this issue. This is just one of many ways in which Christian and Muslim nahdawis worked together in an intricate set of relationships that tied the nineteenth and twentieth centuries to the Ottoman past that preceded them.

\section{History, Record-keeping, and the Ends of Nahda Scholarship}

Irrespective of the different approaches and methodologies deployed by the authors, all contributions take as a point of departure a more general question about what history actually was for nahda scholars. It should be noted that the engagement with history and the heritage of the past was not the exclusive or even privileged domain of nineteenth- and early twentieth-century historians. We have to keep in mind that, while history-writing had long been practiced, history as a professional discipline was itself just emerging. Not only in Egypt, about which we know more thanks to Yoav Di-Capua's exhaustive work on the subject, "the modern idea of history" was acculturated and naturalized in the nineteenth century. It was a form of thought anchored in specific institutions

28 See Islam Dayeh, "From Tashịḥ to Taḥīq: Toward a History of the Arabic Critical Edition," Philological Encounters 4 (2019): 269-72.

29 Ahmed El Shamsy, Rediscovering the Islamic Classics: How Editors and Print Culture Transformed an Intellectual Tradition (Princeton [NJ]: Princeton University Press, 2020). 
and modes of reasoning, and its emergence was intimately linked to modernity and the rise of nationalism. ${ }^{30}$

The individuals mentioned in the contributions to this issue lived at a time when this professionalization accelerated significantly in the Arab provinces of the Ottoman Empire, and beyond. The Christian intellectual Mīkhāîl Mishāqa (1800-1888) authored a history of Syria in the nineteenth century titled al-Jawāb 'alä iqtirāh al-aḥbāb ("Responses to the Suggestions of Loved Ones," 1873), and for the achievement of abandoning the chronicle form he has been called "the first historian" of modern Syria. ${ }^{31}$ Two other early historians were Rizqallāh Ḥassūn (1825-188o) and Rashīd (or Rushayd) Daḥdāḥ (18141889). Both applied historical critical methodology to the origins and history of Islam in order to shed light on the "corruptness of Islam" and the contemporary political field of Muslim-Christian relations. ${ }^{32}$ Only slightly later, Jurjī Zaydān (1861-1914) contributed significantly to history-writing, through a great number of historical works, in which he applied scientific methodology to topics as diverse as the history of the Freemasons (1889), of England (1899), of Islamic civilisation (1902-1906), and of the Arabs before Islam (1908), to mention but a few topics. Yet alongside the emergence of professional history, many writers also engaged in what can be understood as a more popular form of historical writing - a prominent example being the twenty-two historical novels written by Zaydān. ${ }^{33}$ Much like Zaydān, women writers such as Zaynab Fawwāz operated at the intersection of several forms of historical narrative - novels, plays, and even biographical dictionaries—as Marilyn Booth has demonstrated in her work on the subject. ${ }^{34}$

$30 \quad$ See Di-Capua, Gatekeepers, 11.

31 Fruma Zachs, "Mīkhāīl Mishāqa - The First Historian of Modern Syria," British Journal of Middle East Studies 28, no. 1 (2001): 67-87. On al-Jawāb 'alā iqtirāh al-aḥbāb, see also Eugene L. Rogan, "Sectarianism and Social Conflict in Damascus," Arabica 51, no. 4 (2004): 505-507.

32 On Rizqallāh Ḥassūn, see Ami Ayalon, "Hassun and Shidyaq: Pencraft and Survival in Mid-Nineteenth-Century Istanbul," in Cultural Horizons: A Festschrift in Honor of Talat S. Halman, ed. Jayne L. Warner (Syracuse: Syracuse University Press, 2001), 59-68. On Rashīd Daḥdāh, see Jean Ganiage, Les origines du protectorat français en Tunisie (1861-1881) (Tunis: Berg, 2015), 136, fn. 81, and passim, as well as Moncef Chenoufi, Le problème des origines de l'imprimerie et de la presse arabes en Tunisie dans sa relation avec la Renaissance "Nahda" (1847-1887) (Lille: Service de reproduction des thèses Université de Lille III, 1974), 1:182-86.

33 On Zaydān as a historian, see Thomas D. Philipp, "Approaches to History in the Work of Jurji Zaydan," Asian and African Studies 9, no. 1 (1973): 63-85. On his historical novels, see Abjar Bahkou, "Using Fiction as a Vehicle for Popularizing History: Jurji Zaidan's Historical Novels," The Levantine Review 4, no. 1 (2015): 67-85. 
Yet the forms that history took in this period were more capacious than those of the professional discipline. Rather, the past played a role in many other fields of knowledge such as philosophy and logic, grammar and lexicography, linguistics, philology, and adab, or belles lettres. In all these fields, the past functioned as a signifier: where it was not explicitly narrated in historical accounts, the past surfaced in more subtle guises, for example as the "grammatical tradition," or as the "poetic and literary heritage." Above all, we encounter engagements with the past in a significant number of instrumenta studiorum, or study tools, such as encyclopaedias, grammars, catalogues, and scholarly works pertaining to the fields outlined above. Quite often, these works dating to the nineteenth century have been used up until the second half of the twentieth century as instruments for historical and philological study and research by modern scholars. A prominent example is Farḥāt's grammar, which continued to be widely used in the twentieth century. Since they convey an impression of scholarly transparency, they have long escaped notice as reservoirs of historical thought in the nahda. It is the goal of this issue, therefore, to encourage further research that adopts a wider approach to the past in the writing of nahdawis. This promises to shed light on the role history played in nahda discourse - in all its many forms, in the domain of historiography as much as in other scholarly areas.

The interest in history displayed by the nahda writers and scholars discussed in this issue was also rooted in a distinct anxiety about archiving, recordkeeping, and the preservation of the past. As Nadia Bou Ali has observed, nahdawis constructed a veritable "archive" of the past through the publication of dictionaries, encyclopaedias, lexicons, and treatises on history and society. ${ }^{35}$ These and many other works "constitute the arche and techne of national memory insofar as they have the propensity, once given voice, to control a past that they themselves imagine." 36 The impulse to create an archive where there isn't one is common to many of the individuals and projects discussed in this issue, so the nahda-in as much as it engages with the past - is in part a reflection of the concern of nahdawis about the precariousness of archives and record-keeping practices, which produced a turn towards textual and antiquarian methods of preservation. The activities and works of the historian Asad Jibrāīl Rustum (1897-1965), as described in Peter Hill's contribution,

35 Nadia Bou Ali, "Collecting the Nation: Lexicography and National Pedagogy in al-nahda al-arabiyya," in Archives, Museums and Collecting Practices in the Modern Arab World, eds. Sonja Mejcher-Atassi and John Pedro Schwartz (Farnham and Burlington: Routledge, 2012), 36 .

36 Bou Ali, "Collecting the Nation," 36. 
convey a very explicit sense of action carried out in an attempt to document, record, and preserve a past that is in danger of being lost. The same is true in Hilary Kilpatrick's study of Anastās Mārī al-Kirmilī (1866-1947) ${ }^{37}$ Al-Kirmilì’s engagement with numismatics as well as contemporary dialectology as forms of historical enquiry demonstrates that he, like Rustum, was engaged in a project of preserving and recording vestiges of the past. The term al-nahda al-'arabiyya has for a long time been translated as "Arab Renaissance." If the translation "Renaissance" preserves any utility for the study of the nahda, it may be in the way the term has been deployed by scholars of European humanism: a Renaissance that is built around the textual and antiquarian methods linked to preserving the historical record; a Renaissance that is linked to the senses: seeing, touching, holding on to the past in a vivid way. ${ }^{38}$

In some cases, anxieties about the preservation of the past reflect the specific local contexts of the writers in this special issue, not least their own experiences with the rupture of the First World War. Paul Sbath, a Syrian Catholic collector known for the vast collection of manuscripts he assembled over the first half of the twentieth century, conceived of his work as a race to preserve Arabic manuscripts in the face of the migration, warfare, and dislocation caused to individual families in the wake of the First World War. ${ }^{39}$ Moreover, this concern for archiving reflected for some a growing sense of the role of political authorities and rulers in the construction of the past. Asad Rustum based his work on the source material available at the Royal Archives of Egypt at 'Ābdīn Palace. He took an active part in King Fu'ād's (1868-1936) extensive historiographical project launched beginning in 1920, a reminder of the many ways in which individual nahdawis collaborated with representatives of political or religious powers in hopes of better preserving, and therefore controlling, the traces of the past. ${ }^{40}$ In this respect, there are many commonalities between, for example, Asad Rustum's systematic search for documents held in Egyptian archives and the haphazard, but exhaustive presentation of historical documents related to Catholicism in the Middle East assembled in

37 The name is sometimes spelled al-Karmalī or al-Karmilī.

38 Anthony Grafton, Bring Out Your Dead: The Past as Revelation (Cambridge [MA]: Harvard University Press, 2001).

39 Celeste Gianni, "Paul Sbath's Manuscript Library: Conceptualizing the Library of a Syrian Catholic Priest between Europe and the Middle East at the Beginning of the 2oth Century," unpublished paper, forthcoming.

40 On the "Ābdīn House of Records," see Di-Capua, Gatekeepers, 91-140. 
the early twentieth century by the Syrian Catholic scholar Antoine Rabbath $(1867-1913) \cdot{ }^{41}$

It is in this attentiveness to record-keeping that we also see what is perhaps one of the most striking elements of nahda scholarship: the delicate way in which scientific approaches to the past coexisted with what might appear to scholars today as confessional, sectarian, or communalist agendas. The "I" has a place in the preoccupation with the past, and the impulse for record-keeping is in certain contexts tantamount to "recording the self."42 Despite a general turn towards recording and positivist methodology, nahda scholars did not engage with history in a neutral and disengaged fashion. Zaydān wrote his historical works and novels with a clear pedagogical Arab nationalist agenda. ${ }^{43}$ Some of the scholars in this issue, like Cheikho, Rustum, and al-Kirmilī, saw no contradiction between confessional (Christian), nationalistic or patriotic (Arab, Iraqi) identity formation and "scientific" scholarship rooted in positivist study of sources. These three and other scholars invoked similar claims of "documentary exactitude," yet did so in a way that was also aimed at the construction of specific identities. Identity formation and scientific method were not mutually exclusive. Rather a rigorous, scientific approach to the past could feed into the construction of a variety of confessional, communal, national, and many more presentist identities.

Sometimes, identity formation even outweighed all other considerations in nahdawi approaches to the past and became eminently biographical. In Ameuney's works, history is centred on the self and an individual's community. Under the impact of the sectarian violence in Damascus in 186o, Mikhāīl Mishāqa, in his diplomatic reports, traced Muslim-Christian divisions back to the Crusades and the Napoleonic expedition, which, he argued, exacerbated Muslim hatred of Christians. ${ }^{44}$ Confessional impulses are very prominent in the engagement with the past in nineteenth- and early twentieth-century writing, a fact that points to the severely underestimated role of religion in what Albert Hourani called the "liberal age," 45 an era that has long been characterized by its

41 Antoine Rabbath, Documents inédits pour servir à l'histoire du Christianisme en Orient (XVI-XIX siècle), 2 vols. (Paris: A. Picard et Fils, 1905-1914).

42 John-Paul Ghobrial, "The Archive of Orientalism and its Keepers: Re-Imagining the Histories of Arabic Manuscripts in Early Modern Europe," Past \& Present 23o, Supplement 11 (2016): 92. On the autobiographical dimension of Eastern Christian record-keeping practices related to Arabic manuscript collections in European Libraries, see ibid., 106-10. See Philipp, "Approaches to History," 84-85.

44 See Rogan, "Sectarianism," 502-3.

45 Albert Hourani, Arabic Thought in the Liberal Age, 1798-1939 (London/New York: Oxford University Press, 1962). 
purported "secularism." As early as 1970, Hisham Sharabi called this idea into question by factoring religious identity into his classification of tendencies among late nineteenth- and early twentieth-century Arab intellectuals in their approach to the West. ${ }^{46}$ More recently, Ussama Makdisi has drawn attention to the relevance of religion and its strong public presence in what he calls the "Age of Coexistence." ${ }^{47}$ Its "ecumenical frame," which emerged in the nineteenth century, supported overlapping subjectivities and reconciled secularity with religious affiliation in a variety of dynamic configurations. ${ }^{48}$ These subjectivities were not always easily reconciled and could be contradictory. In fact, many of the well-known and much discussed nahda thinkers struggled with their own confessional identity and that of others: Aḥmad Fāris al-Shidyāq (18041887) converted to Protestantism and later to Islam, and Buțrus al-Bustānī (1819-1883), like Ameuney, to Protestantism. Their works reflect a grappling with the issue of sectarian identity, often formed and shaped through historical events experienced as personal history.

The past was not only recorded and archived, or adopted and adapted for identitarian purposes, and thus perceived as disconnected from the present. It was also "made present" by nineteenth- and early twentieth-century scholars and intellectuals who worked to continue and fulfil it. Discontinuities, breaks, turns, and revolutions have frequently been highlighted in scholarly analyses of the nahda, but many scholarly nahda projects are undergirded by intellectual genealogies that reach into the pre-modern past. Hanssen and Weiss have spoken of a "generational movement" that "involved curating a genealogy of knowledge as well as the memory of their intellectual predecessors." ${ }^{\text {49 }}$ The intellectual genealogies are sometimes made explicit, sometimes left implicit. For example, as Rossella De Luca shows in her contribution to this issue, intellectuals and scholars who edited and published different versions of Jirmānūs Farḥat's grammatical work, Aḥmad Fāris al-Shidyāq, Buțrus al-Bustānī, and Saīi al-Khūrī al-Shartūnī (d. 1912) figuring prominently among them, actually saw themselves as fulfilling the aspirations of the work he started, all the while adapting it to different educational contexts. Such a genealogical knowledge that bridged past and present did not necessarily revolve around actual kinship or family networks, but it could do so, as in the case of the Damascene Hanbali al-Shațịi family. As Torsten Wollina describes in his contribution, between the

\footnotetext{
46 Hisham Sharabi, Arab Intellectuals and the West:The Formative Years, 1875-1914 (Baltimore/ London: The John Hopkins Press, 1970).

47 Ussama Makdisi, Age of Coexistence: The Ecumenical Frame and the Making of the Modern Arab World (Oakland [CA]: University of California Press, 2019).

48 See Makdisi, Age of Coexistence, 7-8 and passim.

49 Hanssen and Weiss, "Introduction," 29.
} 
early nineteenth and mid-twentieth century, members of the family created a veritable diachronic network around activities like writing, copying, printing, and collecting books. In these and other cases, nahdawis imagined themselves as part of a genealogy that stretched far backwards in time even as they set their sights on visions of change in the future. The special issue makes these genealogies explicit in hopes of better understanding the ways in which nahdawis imagined their own relationship to historical time - those who presaged them as well as those who would follow.

\section{Decentring Nahḍ Discourse and Scholarship}

Like any other field of scholarly inquiry, the study of nahda discourse and scholarship needs to be circumscribed in certain ways so as to constitute a distinct object of study. Yet the question of what counts as such has often remained unanswered; instead, certain "centrisms" have imperceptibly influenced the delimitations and boundaries of scholarship about the nahda. One of the most fateful "centrisms" is a geographical one: studies of nahda scholars and thinkers for the geographical region of Egypt and Bilād al-Shām abound, but to consign participation in nahda discourse to this region is too limited a view. Scholars engaging with the past in the ways described above stemmed from and flourished in a variety of different milieus. Even more importantly, their biographies often bear witness to a significant mobility, even on a global scale. The biography of Rizqallāh Ḥassūn, who in 1854 or 1855 launched the first private Arabic newspaper Mir'ät al-Aḥwäl ("Mirror of Events"), is a case in point: a native of Aleppo, he embarked on travels to London and Paris before he proceeded to Cairo and to Istanbul, where he settled down and switched between business, literary, and journalistic activities. ${ }^{50}$ Alphonse Mingana was born near Zakho, in what is today northern Iraq, and moved to England in 1913, where he soon became curator for the oriental manuscript collection at Manchester. ${ }^{51}$ To mention only two of the examples discussed in the special issue: Ameuney lived in England and taught Arabic at King's College in London, and Rustum even studied at the University of Chicago. Such biographies alone call for geographically decentring the nahda narrative and opening it to global historical inquiry.

$50 \quad$ Ayalon, "Hassun and Shidyaq," 60.

51 On Alphonse Mingana, see Tijmen C. Baarda, "Firmly Established in Early TwentiethCentury Orientalism: Alphonse Mingana among his Fellow Scholars," Journal of Syriac Studies 19, no. 1 (2016): 3-34. 
There is a further reason for decentring the nahda that becomes clearer if we consider the diverse audiences, publication strategies, and media in which nahda discourses circulated. Not least because of their biographies, many nineteenth- and early twentieth-century nahdawis wrote with several readerships in mind-local and communal readerships who participated in projects of identity formation through the reception of the works, as well as imperial (Ottoman, Khedivial) readerships and European readerships. Even in cases in which the scholars themselves did not move, infrastructure and communication allowed discourses to circulate on a global scale. These observations are not meant to reintroduce, through the backdoor, Eurocentric explanations of nineteenth-century developments and epistemological shifts that scholars have long questioned. ${ }^{52}$ Instead, scholars and their written articulations must be understood within a variety of contexts: One of the important points that emerge from the case studies in this special issue is the extent to which nahda scholars developed their approaches not only with a view towards capturing the interests of Arabic-speaking, but also European audiences. We see this, for example, in Cheikho's engagement with the French Orientalist Ernest Renan's (1823-92) ideas about Semitic peoples and their languages, or, to mention a well-known example not discussed in this issue, Jamāl al-Dīn al-Afghānī's (1839-97) disputes with Renan. Many more examples could be mentioned, some of them even from the Americas: The memoirs of the Greek Orthodox emigrant Ibrāhīm 'Arbīlī, or Abraham Arbeely, published in 1913, reflect back on recent history, notably the 1860 massacre in Damascus. Decrying "Islamic fanaticism," the work clearly responds to sectarian discourses forged between Europe and Lebanon and simultaneously bears witness to the author's struggle for integration in American society with the help of narratives of persecution. ${ }^{53}$

On the one hand, these cases demonstrate the importance of racial, orientalist, and sectarian discourses as a topic of concern to nahdawis. We thereby observe that conversations and controversies cannot be simply drawn on an East-West dichotomy. The multiple audiences and reading publics involved created a multitude of possibilities for different individuals to (dis)agree with one another, despite at times sharing important facets of identity. This could sometimes produce strange outcomes, for example in the reactions of the historian and literary critic Muhammad Kurd 'Alī (1876-1953) to both Henri

$5^{2}$ On the discussions about moving "beyond Eurocentrism," see the comments in Sheehi, "Towards a Critical Theory," $271-72$.

53 On Ibrāhīm 'Arbīlī, see Feras Krimsti, "The Massacre in Damascus, July 186o," in ChristianMuslim Relations: A Bibliographical History, vol. 18, The Ottoman Empire (1800-1914), eds. David Thomas and John A. Chesworth (Leiden: Brill, 2021), 394-95. 
Lammens (1862-1937) and Louis Cheikho. He faulted the two Jesuit scholars for crediting literary accomplishments exclusively to Christian Arabs, painting both with a single brush although the former was Belgian and the latter born in the Ottoman Empire. ${ }^{54}$ On the other hand, the cases show that we cannot quite make sense of the positions of these individuals vis-à-vis the past without situating them within a wider geographical framework than just their immediate milieu or the Ottoman Empire.

If the case studies brought together in this special issue shed light on a geography of the nahda that stretches far beyond the Arab world, they also suggest the importance of decentring our understanding of the nahda with regard to its purported "secularism." Ameuney's dream of a Protestant Middle East does not sit comfortably with traditional conceptions of the nahda that flowed from the pens of Buțrus al-Bustānī, Nāṣîf al-Yāzijī (18oo-71), and Aḥmad Fāris al-Shidyāq. Indeed, the apparent sectarian inclinations of scholars like Louis Cheikho, from a Christian perspective, or Jamāl al-Dīn al-Qāsimī (1866-1914), from a Salafi perspective, ${ }^{55}$ may explain the fact that such individuals have been left out of a tradition of scholarship that has wanted to cling to Hourani's original vision of a "liberal age." Be that as it may, it is clear from the contributions assembled here that there existed some strands of nahda scholarship that preserved, or even privileged, a place for religion alongside aspirations for progress, modernity, and change. In this way, it becomes possible to glimpse a vision of the nahda that engages as much with ecumenical or humanist projects of the time as the sectarian ones that were lambasted at least by some nahdawis. It is also an approach that resonates with current attempts to reevaluate secularism — its aspirations, its realities, and its legacies—as has been taking place across several fields in recent years. ${ }^{56}$ What more could we learn about the nahda if we explored it in the context of other analytical frameworks

54 Muhammad Kurd 'Alī, al-Islām wa-l-haḍāra al-'arabiyya (Cairo: Maṭba'at Lajnat al-Ta’līf wa-l-Tarjama wa-l-Nashr, 1968) 1:33. See also Joseph H. Escovitz, "Orientalists and Orientalism in the Writings of Muhammad Kurd 'Ali," International Journal of Middle East Studies 15, no. 1 (1983): 100.

55 David Dean Commins, Islamic Reform: Politics and Social Change in Late Ottoman Syria (New York/Oxford: Oxford University Press, 199o).

56 Rajeev Bhargava, ed., Secularism and its Critics (Delhi/Oxford: Oxford University Press, 1998); Talal Asad, Formations of the Secular: Christianity, Islam, Modernity (Stanford [CA]: Stanford University Press, 2003); Craig J. Calhoun, Mark Juergensmeyer, and Jonathan VanAntwerpen, eds., Rethinking Secularism (Oxford: Oxford University Press, 2011); Saba Mahmood, Religious Difference in a Secular Age: A Minority Report (Princeton [NJ]: Princeton University Press, 2016); and most recently Philip G. Nord, Katja M. Guenther, and Max Weiss, eds., Formations of Belief: Historical Approaches to Religion and the Secular (Princeton [NJ]: Princeton University Press, 2019). 
used for this period, for example that of religious internationalism or the resurgence of religion in the nineteenth century? Future research has much work to do to recover the voices of individuals that have not typically been considered and to incorporate them more effectively into a general history of the nahda, one that stretches far beyond Egypt and Bilād al-Shām.

\section{A History of Possibilities}

On the most basic level, this special issue is a reflection of the fact that we now know more than ever before about the vast world of writers, periodicals, and readers that populated the nineteenth- and twentieth-century world of the nahda. But already in 1983, Hourani warned against the dangers associated with any approach that emphasized a number of individuals or assumed that individuals were "broadly representative of certain tendencies of generations:"

There is a risk therefore of imposing an artificial unity on their thought, of making it seem more systematic and consistent than in fact it was, and also of giving the impression that they were more important and original than they really were. ${ }^{57}$

Even with our increased knowledge of writers and texts, therefore, many dangers remain in writing a history of the nahda as a history of ideas, intellectuals, and texts without sufficient attention to broader social trends and everyday realities-as if the mental world of Buṭus al-Bustānī alone could represent the horizons of the Arab nahda.

Instead, we hope that by focusing on approaches to the past this special issue will contribute to a history of the nahda as a "history of possibilities." Ideally, this history of possibilities will recover a wider circle of people that have yet to be incorporated as well as a wider geography of actors, of diverse confessions to be sure, including Middle Eastern, European and even American actors. Seeing the nahda in this decentred way will also help us recover a better sense of the simultaneity of a diverse spectrum of voices and perspectivespositivist, communalist, nationalist, religious, and many more. No matter how radically different the ideas held by these individuals were, they all asserted their role as the rightful guardians of the past. The critical mass of scholars now working on this subject gives much hope for a more three-dimensional history of the nahda that is emerging at the intersection of all these boundaries. 


\section{Bibliography}

Anonymous, al-Shahbä' 9, no. 1, 2, 3 (1934).

Asad, Talal. Formations of the Secular: Christianity, Islam, Modernity. Stanford [CA]: Stanford University Press, 2003.

Ayalon, Ami. "Hassun and Shidyaq: Pencraft and Survival in Mid-Nineteenth-Century Istanbul." In Cultural Horizons: A Festschrift in Honor of Talat S. Halman, edited by Jayne L. Warner, 59-68. Syracuse: Syracuse University Press, 2001.

Baarda, Tijmen C. "Firmly Established in Early Twentieth-Century Orientalism: Alphonse Mingana among his Fellow Scholars." Journal of Syriac Studies 19, no. 1 (2016): 3-34.

Bahkou, Abjar. "Using Fiction as a Vehicle for Popularizing History: Jurji Zaidan's Historical Novels." The Levantine Review 4, no. 1 (2015): 67-85.

Barbir, Karl K. "Memory, Heritage, and History: The Ottoman Legacy in the Arab World." In Imperial Legacy: The Ottoman Imprint on the Balkans and the Middle East, edited by L. Carl Brown, 100-114. New York: Columbia University Press, 1996.

Bashkin, Orit. "Looking Forward to the Past: Nahda, Revolution, and the Early Ba'th in Iraq." In Other Renaissances: A New Approach to World Literature, edited by Brenda Deen Schildgen, Gang Zhou, and Sander L. Gilman, 59-86. Basingstoke: Palgrave Macmillan, 2006.

Bhargava, Rajeev, ed. Secularism and its Critics. Delhi/Oxford: Oxford University Press, 1998.

Booth, Marilyn. Classes of Ladies of Cloistered Spaces: Writing Feminist History through Biography in Fin-de-siecle Egypt. Edinburgh: Edinburgh University Press, 2015.

Bou Ali, Nadia. "Collecting the Nation: Lexicography and National Pedagogy in alnahda al-'arabiyya." In Archives, Museums and Collecting Practices in the Modern Arab World, edited by Sonja Mejcher-Atassi and John Pedro Schwartz, 33-56. Farnham and Burlington: Routledge, 2012.

Calhoun, Craig J., Mark Juergensmeyer, and Jonathan VanAntwerpen, eds. Rethinking Secularism. Oxford: Oxford University Press, 2011.

Chenoufi, Moncef. Le problème des origines de l'imprimerie et de la presse arabes en Tunisie dans sa relation avec la Renaissance "Nahda" (1847-1887). Lille: Service de reproduction des thèses Université de Lille III, 1974.

Commins, David Dean. Islamic Reform: Politics and Social Change in Late Ottoman Syria. New York/Oxford: Oxford University Press, 1990.

Dayeh, Islam. "From Tashịh to Tahqiìq: Toward a History of the Arabic Critical Edition," Philological Encounters 4 (2019): 245-299.

Di-Capua, Yoav. Gatekeepers of the Arab Past: Historians and History-Writing in Twentieth-Century Egypt. Berkeley/London: University of California Press, 2009.

Edwards, Anthony. "Fact or Fiction? In Search of the 'Learned Council' of Ğirmānūs Farhạat." Journal of Arabic and Islamic Studies, no. 18 (2018): 1-21. 
Elshakry, Marwa. Reading Darwin in Arabic, 1860-1950. Chicago: The University of Chicago Press, 2014.

El Shamsy, Ahmed. Rediscovering the Islamic Classics: How Editors and Print Culture Transformed an Intellectual Tradition. Princeton [NJ]: Princeton University Press, 2020 .

Escovitz, Joseph H. "Orientalists and Orientalism in the Writings of Muhammad Kurd 'Ali." International Journal of Middle East Studies 15, no. 1 (1983): 95-109.

Ganiage, Jean. Les origines du protectorat français en Tunisie (1861-1881). Tunis: Berg, 2015 .

Ghobrial, John-Paul. "The Archive of Orientalism and its Keepers: Re-Imagining the Histories of Arabic Manuscripts in Early Modern Europe." Past \& Present 230, Supplement 11 (2016): 90-111.

Gianni, Celeste. "Paul Sbath's Manuscript Library: Conceptualizing the Library of a Syrian Catholic Priest between Europe and the Middle East at the Beginning of the 2oth Century." Unpublished paper, forthcoming.

Grafton, Anthony. Bring Out Your Dead: The Past as Revelation. Cambridge [MA]: Harvard University Press, 2001.

Hanssen, Jens, and Max Weiss. "Introduction: Language, Mind, Freedom and Time: The Modern Arab Intellectual Tradition in Four Words." In Arabic Thought Beyond the Liberal Age: Towards an Intellectual History of the Nahda, edited by Jens Hanssen and Max Weiss, 1-37. Cambridge: Cambridge University Press, 2016.

Hill, Peter. Utopia and Civilisation in the Arab Nahda. Cambridge: Cambridge University Press, 2020.

Hourani, Albert. Arabic Thought in the Liberal Age, 1798-1939. London/New York: Oxford University Press, 1962.

Hourani, Albert. Arabic Thought in the Liberal Age, 1798-1939. Cambridge: Cambridge University Press, ${ }^{2} 1983$.

Krimsti, Feras. "The Massacre in Damascus, July 186o." In Christian-Muslim Relations: A Bibliographical History, vol. 18, The Ottoman Empire (1800-1914), edited by David Thomas and John A. Chesworth, 378-406. Leiden: Brill, 2021.

Kurd 'Alī, Muḥammad. Al-Islām wa-l-ḥaḍāra al-'arabiyya, 2 vols. Cairo: Mațba'at Lajnat al-Ta'lif wa-l-Tarjama wa-l-Nashr, 1968.

Makdisi, Ussama. Age of Coexistence: The Ecumenical Frame and the Making of the Modern Arab World. Oakland [CA]: University of California Press, 2019.

Mahmood, Saba. Religious Difference in a Secular Age: A Minority Report. Princeton [NJ]: Princeton University Press, 2016.

Nord, Philip G., Katja M. Guenther, and Max Weiss, eds. Formations of Belief: Historical Approaches to Religion and the Secular. Princeton [NJ]: Princeton University Press, 2019.

Philipp, Thomas D. "Approaches to History in the Work of Jurji Zaydan." Asian and African Studies 9, no. 1 (1973): 63-85. 
Qar’alī, Būlus. Al-Nașrāniyya wa-l-Islām: Difā' mansūb ilā al-ab Jurjus Rāhib Dayr Mār Sam‘ān al-Baḥrī. Bayt Shabāb: Maṭba'at al-'Alam, 1933.

Rabbath, Antoine. Documents inédits pour servir à l'histoire du Christianisme en Orient (XVI-XIX siècle), 2 vols. Paris: A. Picard et Fils, 1905-1914.

Reimer, Michael J. "Egyptian Views of Ottoman Rule: Five Historians and Their Works, 1820-1920," Comparative Studies of South Asia, Africa and the Middle East 31, no. 1 (2011): 149-163.

Rogan, Eugene L. "Sectarianism and Social Conflict in Damascus." Arabica 51, no. 4 (2004): 505-507.

[Sa'd, Aghnāțiyūs, ed.] Rawā̄ì al-yūbül al-miawì al-thānī li-takhlìd faqūd al-iilm wa-l-fậīla al-nābigha al-Muțrān Jirmānūs Farhạā, 2 parts in 1 volume. Aleppo: al-Maṭba'a al-Mārūniyya, 1934.

al-Ṣaffār, Muḥammad. Disorienting Encounters: Travels of a Moroccan Scholar in France in 1845-1846: The Voyage of Muhammad aș-Ṣaffār, edited and translated by Susan Gilson Miller. Berkeley: University of California Press, 1992.

Sajdi, Dana. The Barber of Damascus: Nouveau Literacy in the Eighteenth-Century Ottoman Levant. Stanford: Stanford University Press, 2013.

Sajdi, Dana. "Decline, its Discontents and Ottoman Cultural History: By Way of Introduction.” In Ottoman Tulips, Ottoman Coffee: Leisure and Lifestyle in the Eighteenth Century, edited by Dana Sajdi, 1-40. London: I.B. Tauris, 2007.

Salibi, Kamal. A House of Many Mansions: The History of Lebanon Reconsidered. London: I.B. Tauris, 1988.

Sharabi, Hisham. Arab Intellectuals and the West: The Formative Years, 1875-1914. Baltimore/London: The John Hopkins Press, 1970.

Sheehi, Stephen. "Unpacking Modern Arab Subjectivity: Reading al-Mu'allim Butrus al-Bustani's 'Nafir Suriya'." The Arab Studies Journal 6, no. 1 (1998): 87-99.

al-Tahtawi, Rifa'a Rafic. An Imam in Paris: Account of a Stay in France by an Egyptian Cleric (1826-1831), translated by Daniel L. Newman. London: Saqi, 2004.

Watenpaugh, Keith David. Being Modern in the Middle East: Revolution, Nationalism, Colonialism, and the Arab Middle Class. Princeton [NJ]: Princeton University Press, 2006.

Wien, Peter. Arab Nationalism: The Politics of History and Culture in the Modern Middle East. Abingdon: Routledge, 2017.

Winckler, Barbara. "Embarking upon a New Era through an Old Genre: Biographical Essays in Journals of the Nahḍah Period-Ǧurǧ̄i Zaydān and al-Hilāl's Early Years as Example." Oriente Moderno 99 (2019): 68-93.

Zachs, Fruma. "Mīkhā̄ìl Mishāqa — The First Historian of Modern Syria." BritishJournal of Middle East Studies 28, no. 1 (2001): 67-87.

Zayyāt, Ḥabīb. Review of "Tārīkh al-Shām li-l-Khūrī Mīkhā̄̄ll Burayk." Al-Mashriq 35 (1937): 209-217. 